\title{
Zagrożenia osuwiskowe na trasie budowy drogi ekspresowej S-7 na odcinku Lubień-Naprawa (Karpaty fliszowe)
}

\author{
Antoni Wójcik ${ }^{1}$, Sebastian Jurczak², Mariusz Wnuk², Krzysztof Janik²
}

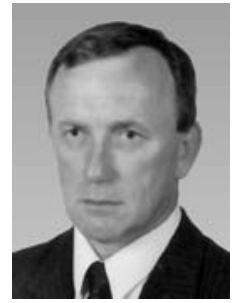

A. Wójcik

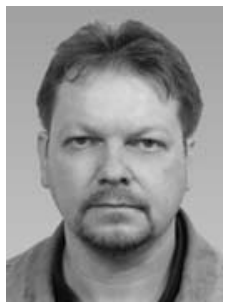

S. Jurczak

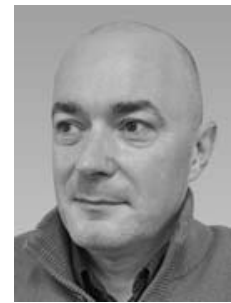

M. Wnuk

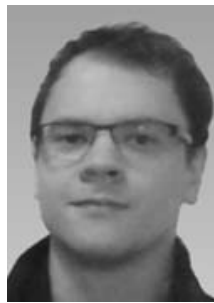

K. Janik

Landslides hazard in the construction of the expressway S-7 on the Lubień-Naprawa section (Flysch Carpathians). Prz. Geol., 67: 388-396; doi: 10.7306/2019.33

A b s tr a $\mathrm{c}$ t. Landslide recognition is an important task for designers and contractors during the road construction process. The problems that contractors often face is insufficient recognition of the geological structure (at the design stage), too small area of purchased land under the "ZRiD"decision, or the inability of fast responding to emerging threats. The studies described in this article shed more light on the complexity of slope deformation as a result of landslide processes. During the constructing of the expressway $S-7$, the problems related to deep landslide processes occurred, which most probably were associated with poorly recognized old "rocky-weathering material" type of landslide. The geological survey performed during the construction of this road, confirmed the occurrence of deep $(>20 \mathrm{~m})$ displacements, recorded by the inclinometer measurements. These deep displacements are linked to a large landslide with a main scarp located in the region of Mt. Cymbałowa Góra.

Keywords: mass movements, Flysch Carpathians, landslide, Southern Poland

Projektanci inwestycji drogowych muszą się mierzyć z różnymi problemami geologiczno-inżynierskimi, a na obszarze południowej Polski dość często mają do czynienia z zagrożeniem osuwiskowym. Dokładne rozpoznanie tego zagrożenia jest zazwyczaj trudne, gdyż procesy osuwiskowe mają złożony przebieg, stymulowany przez wiele czynników wewnętrznych i zewnętrznych. Przykładem inwestycji planowanej na terenie osuwiskowym jest odcinek drogi ekspresowej S-7, budowanej obecnie na terenie Beskidu Wyspowego między Lubniem a Rabką (ryc. 1). Na południe od miejscowości Lubień trasa tej drogi przebiega przez tereny objęte osuwiskami (ryc. 2). Osuwiska zagrażają również budowie tej drogi na odcinku między Krakowem a Lubniem (Pietrusza, Pletnia, 2009), a w czasie budowy odcinka między Lubniem a Krzeczowem problemy związane z występowaniem osuwisk okazały się bardziej złożone, niż wynikało to z uprzedniego rozpoznania. $\mathrm{Z}$ podobnymi problemami zetknięto się wcześniej w trakcie budowy tej drogi k. Mogilan (Królikiewicz, 1978) i niestety jej użytkownicy do dziś ponoszą konsekwencje złego rozpoznania zagrożenia osuwiskowego.

Artykuł przybliża złożoność zagadnienia deformacji stoków w wyniku procesów osuwiskowych. Właściwa analiza procesów osuwiskowych wymaga przede wszystkim dużego doświadczenia w dziedzinie badań geologicznych.

\section{OBSZAR BADAŃ}

Rozpoznanie zagrożenia osuwiskowego prowadzono na trasie budowy nowej drogi ekspresowej S-7, na odcinku pomiędzy miejscowościami Lubień i Naprawa. W podłożu tego obszaru występują utwory płaszczowiny magurskiej, należące do podjednostki raczańskiej (Książkiewicz i in., 2017). Dominują wychodnie utworów wieku paleogeńskiego, wśród których wyróżnia się łupki pstre, warstwy hieroglifowe i piaskowce magurskie (Książkiewicz i in., 2017; Burtan, Szymakowska, 1966). Łupki pstre ukazują się $\mathrm{w}$ osiach antyklin, a piaskowce magurskie wypełniają synkliny. Na utwory czwartorzędowe składają się gliny i gliny soliflukcyjno-deluwialne z rumoszem oraz osady rzeczne wypełniające dna dolin (Wójcik, Rączkowski, 1994).

Najstarszymi utworami odsłaniającymi się na tym terenie są łupki pstre. Należą do nich łupki ilaste i mułowce czerwone z cienkimi wkładkami łupków zielonych i niebieskawo-popielatych, które lokalnie przeważają nad łupkami czerwonymi. Są to łupki miękkie, łatwo ulegające rozwarstwieniu. Wkładki cienkoławicowych piaskowców towarzyszą głównie łupkom niebieskopopielatym. W górnej części profilu występują przeważnie miękkie łupki ilaste, czerwone i zielone, o podobnej miąższości.

$\mathrm{Na}$ łupkach pstrych leżą szeroko rozprzestrzenione warstwy hieroglifowe. Jest to zespół skalny o miąższości 30-50 m, złożony głównie z szarozielonych łupków ilastych, grubołupliwych z wkładkami ciemnoszarych, brunatnych i czarnych ilastych łupków wapnistych. Wyżej w profilu warstw hieroglifowych występują mułowce wapnisto-margliste, przeważnie szarozielone, grubołupliwe, bezwapniste oraz rozpadające się kostkowo piaskowce. Na obszarze badań wyróżnia się warstwy hieroglifowe w facji beloweskiej, składające się z łupków jasnozielonych, zielonawoniebieskich i niebieskosiwych. Piaskowce są bogate w hieroglify i silnie mikowe, niebieskawe i szaroniebieskawe, o ciosie powodującym rozpadanie się ławic na płyty.

\footnotetext{
${ }^{1}$ Państwowy Instytut Geologiczny - Państwowy Instytut Badawczy, Oddział Karpacki, ul. Skrzatów 1, 31-560 Kraków; antoni.wojcik@pgi.gov.pl

2 AQUA-SOIL Mariusz Wnuk, ul. Sosnowiecka 94, 42-530 Dąbrowa Górnicza; mariusz.wnuk@aquasoil.pl
} 


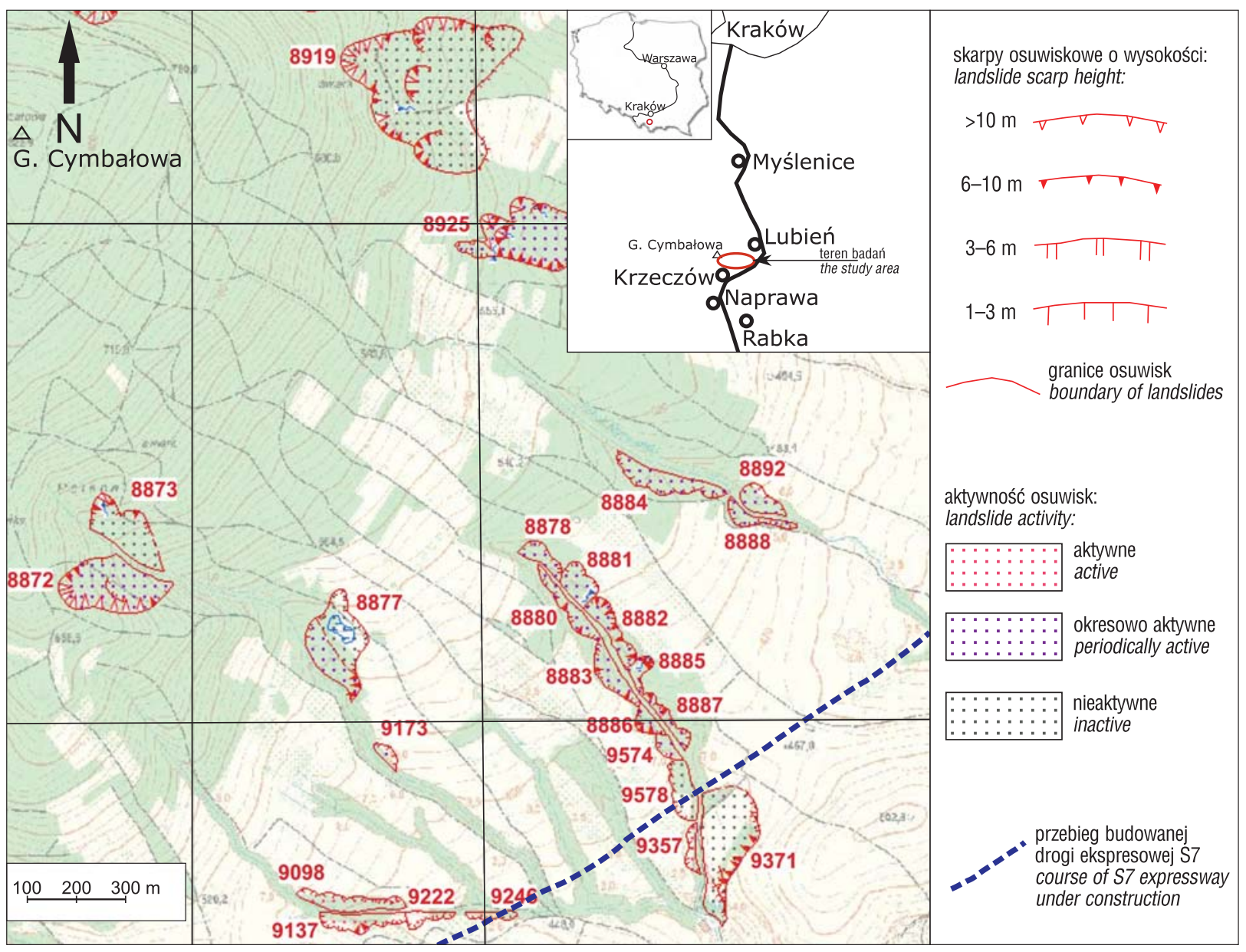

Ryc. 1. Tereń badań wzdłuż trasy S-7 k. Lubnia; rozmieszczenie osuwisk w systemie SOPO wg Kaczmarczyk i in., 2010 (zmienione)

Fig. 1. Location of the test site; distribution of landslides according to the SOPO system, after Kaczmarczyk et al., 2010 (modified)

Warstwy hieroglifowe są przykryte piaskowcami magurskimi facji muskowitowej, a granica między tymi skałami jest nieostra. Piaskowce magurskie sa gruboławicowe (o miąższości ławic do 2-3 m), średnioziarniste, rzadziej gruboziarniste. Rozdzielają je cienkie warstwy (do kilkunastu $\mathrm{cm}$ miąższości) szarych łupków marglistych (Borysławski, 1985). W piaskowcach tych spotyka się także kompleksy łupków o miąższości do $50 \mathrm{~m}$, z cienkoławicowymi piaskowcami (łupki śródmagurskie).

Wyniki wcześniejszych badań dowodzą, że teren Beskidu Wyspowego, przez który przebiega budowana droga S-7, może współcześnie podlegać procesom osuwiskowym. Wskazywali na to m.in. Jakubowski i Ostaficzuk (1962), Michalik (1970), Bober (1983, 1984, 1994), Margielewski (2006) oraz Książkiewicz i in. (2017).

\section{STAN ROZPOZNANIA PROCESÓW OSUWISKOWYCH DO 2017 r.}

Pierwszym etapem rozpoznania terenu budowy drogi S-7 między Lubniem a Naprawą było szczegółowe zbadanie osuwisk, które zlokalizowano na tej trasie na zboczach dolin wciosowych. Przeprowadzono powierzchniowe kartowanie geologiczno-inżynierskie i wykonano kilka wierceń. Rozpoznano zespół zsuwów powierzchniowych o miąższości 2-5 m i różnej aktywności. Na podstawie wyników tych badań, które wraz z mapą geologiczno-inżynierską obrazującą obszary osuwiskowe zawarto w dokumentacji (Grzywacz, Kicińska, 2000), zmieniono trajektorię planowanej drogi, przesuwając ją o ok. $100 \mathrm{~m} \mathrm{w}$ kierunku północnym. Prawdopodobnie dokonano tego, aby uniknąć przebiegu drogi S-7 w pobliżu nieaktywnego osuwiska strukturalnego (ryc. 1).

W 2010 r. w gminie Lubień dokonano rejestracji osuwisk (Kaczmarczyk i in., 2010), w ramach której, zgodnie z instrukcją Grabowskiego i in. (2008), opracowano mapy i karty rejestracyjne osuwisk. Wzdłuż doliny cieku przecinającego trasę projektowanej drogi S-7 potwierdzono występowanie 12 osuwisk o różnej wielkości i aktywności (ryc. 1). Oceniono, że powierzchnia poślizgu największego osuwiska, nr 9371 (ryc. 1), znajduje się na głębokości 9,0 m p.p.t. (Kaczmarczyk i in., 2010).

Po ustaleniu lokalizacji drogi S-7 oraz obiektów z nią związanych, na podstawie danych $\mathrm{z}$ otworów wykonanych zgodnie zaleceniami GDDKiA (Nowacki, 1999), opracowano dokumentację geologiczną okolic drogi S-7 na odcinku Lubień-Rabka Zdrój (Pietruszka i in., 2010). W dokumentacji tej rejon Lubnia zaliczono do terenów aktywnych osuwiskowo. Nowa trasa drogi S-7 ma przecinać osuwisko zlokalizowane po prawej stronie doliny (bez nazwy), oznaczone na mapach SOPO jako 9578 (ryc. 1). Głębokość powierzchni poślizgu tego osuwiska oszacowano na $5,0 \mathrm{~m}$ p.p.t. W otworach $\mathrm{w}$ rejonie podpory P-2 k. Lubnia (ryc. 2) nie stwierdzono powierzchni poślizgu oraz śladów zlustrowań (Pietruszka i in., 2010).

Kolejny etap prac polegał na wykonaniu badań kontrolnych i szczegółowym rozpoznaniu terenów osuwiskowych 


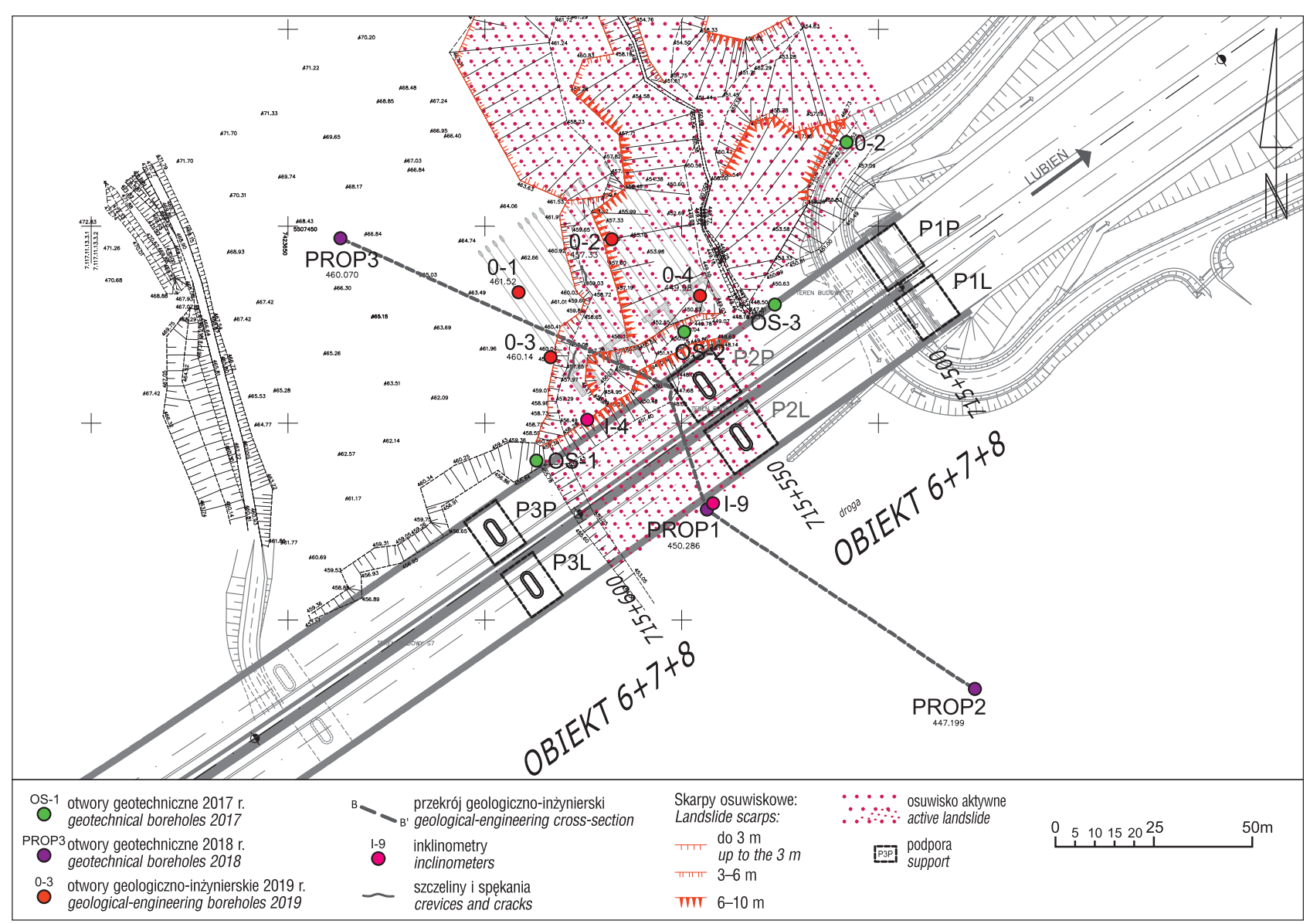

Ryc. 2. Lokalizacja otworów badawczych i czynnych osuwisk na trasie projektowanej drogi S-7 w rejonie podpory P-2 w Lubniu Fig. 2. Location of the investigation boreholes and active landslides along the course of the designed expressway S-7 in Lubien

otworami badawczymi (Jurczak i in., 2016). W jednym z otworów kontrolnych (rejon archiwalnego otworu BK 3.4 wg Pietruszki i in., 2010) stwierdzono, że do głębokości 2,1 m występują grunty plastyczne, świadczące o istnieniu płytkiego zsuwu, a na głębokości 20,0 m p.p.t. wyraźne zlustrowanie. W związku z tym zalecono zainstalowanie głębokiego inklinometru (25-30 m p.p.t.), obejmującego strefę ścięcia (Jurczak i in., 2016).

\section{UAKTYWNIENIE SIE PROCESÓW OSUWISKOWYCH LATEM 2017 r.}

W roku 2017 wykonawca drogi przystapił do budowy podpór planowanej estakady S-7 (ryc. 2). Dostępny wąski pas drogowy zdeterminował wykonanie podcięcia stoku o wysokości ok. 10-12 m. Dno wkopu znajdowało się wówczas na poziomie 447,5 m n.p.m.

W ramach planowanego monitoringu obszarów, na których istniało prawdopodobieństwo ruchów osuwiskowych, oraz w wyniku zaleceń zwartych w opracowaniu kontrolnym (Jurczak i in., 2016) ponad podporą P-2 założono inklinometr I-4 (ryc. 2, 3), w celu monitorowania aktywności ruchów osuwiskowych w czasie wykonywania prac budowlanych.

W czerwcu 2017 r. w inklinometrze I-4 na głębokości 18,0 i $23,0 \mathrm{~m}$ p.p.t. zanotowano niewielkie wychylenia kolumny inklinometrycznej, wynoszące ok. 5-6 mm (ryc. 3).

W lipcu i sierpniu 2017 r. skarpa ponad budowaną podporą P-2 utraciła stateczność i osunęła się na nią. Powyżej

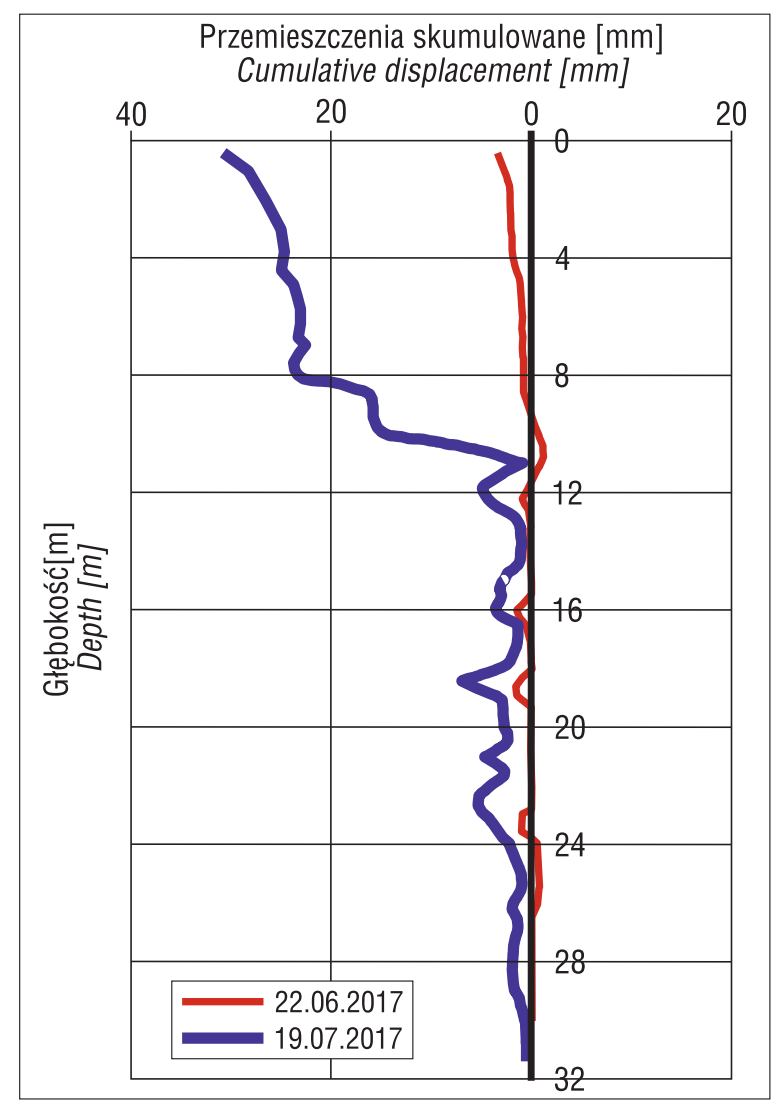

Ryc. 3. Krzywe przemieszczeń w inklinometrze I-4 Fig. 3. Displacement curves in inclinometer I-4 
inklinometru I-4 (ok. $5 \mathrm{~m}$ ponad nim) pojawiła się szczelina długości ok. $50 \mathrm{~m}$ o przebiegu N-S (ryc. 2, 4). Przekształciła się ona w skarpę główną osuwiska o zrzucie do 1,5 m. Poniżej skarpy głównej pojawiło się kilka wewnątrzosuwiskowych skarp wtórnych, a powyżej niej utworzyły się szczeliny (ryc. 2, 4).

W wyniku uaktywnienia się osuwiska inklinometr I-4 został ścięty między 9 a 10 m p.p.t. (442,5 m n.p.m.), czyli poniżej spagu ławy betonowej podpory P-2. W inklinome- trze tym zarejestrowano również przemieszczenia na głębokości 24,3 m i 27,3 m (ryc. 3). W ramach doraźnych prac zabezpieczających wykonawca robót odciążył stok, usuwając część gruntów koluwialnych.

We wrześniu 2017 r. obserwowano ciagłą aktywność osuwiska, objawiającą się naporem mas koluwialnych na ściankę larsenowską zabezpieczającą podpory. Pomiar inklinometryczny wskazywał na występowanie ścięcia na głębokości 8,5-9,0 m p.p.t. (ryc. 3).
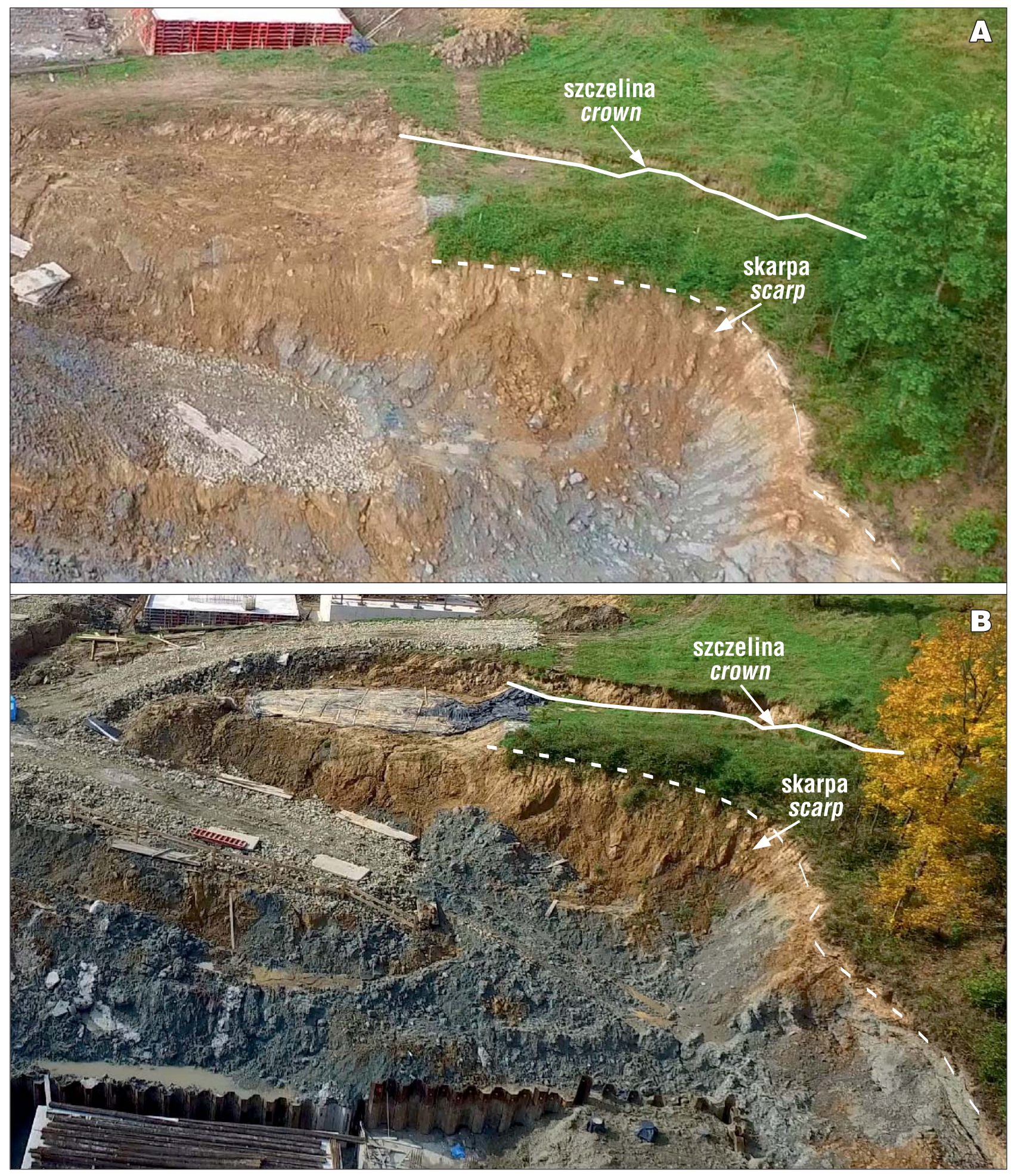

Ryc. 4. Aktywna część osuwiska w rejonie budowanej drogi ekspresowej S-7 w Lubniu: A - 26.08.2017 r.; B - 30.09.2017 r. Fot. S. Jurczak

Fig. 4. Active part of the landslide in the construction of the expressway S-7 in Lubien: A - 26.08.2017; B - 30.09.2017 Photo S. Jurczak 
Uznano, że inicjacja tych ruchów miała związek z głębokim wykopem oraz długotrwałymi opadami (Pyrc, 2018). We wrześniu 2017 r. miesięczna suma opadów zmierzona w pobliskiej stacji meteorologicznej w Krzeczowie wyniosła $193,5 \mathrm{~mm}$, podczas gdy średnia $\mathrm{z}$ wielolecia wynosi 74,2 mm (Pyrc, 2018).

W związku z uruchomieniem procesów osuwiskowych oraz koniecznością zabezpieczenia drogi przed skutkami ruchów masowych wykonano kolejne prace rozpoznawcze - pełnordzeniowe wiercenia, dodatkowe badania podłoża gruntowego i dokumentacje geologiczno-inżynierskie (Jurczak, Russocki, 2017; Jurczak i in., 2017, 2019; Wnuk i in., 2018). Stwierdzono, że ruchom grawitacyjnym i deformacjom podlega strefa gruntu w przedziale rzędnych 434,0-440,0 m n.p.m. (Jurczak i in., 2017, 2019; Wnuk i in., 2018).

Na kolejnym etapie rozpoznania w otworze PROP-1, to jest poza strefą wcześniej wyznaczonych osuwisk (ryc. 1), zamontowano kolumnę inklinometryczną I-9 (492 m n.p.m.; ryc. 2, 5; Wnuk i in., 2018). Celem tego zabiegu była obserwacja dalszych głębokich przemieszczeń, na które wskazywały liczne powierzchnie poślizgu w rdzeniach wiertniczych, które objawiały się w postaci luster, czasami z wyraźnymi rysami ślizgowymi. Powierzchnie te stwierdzono przewa- żnie w seriach skalnych zawierających znaczną ilość czerwonych łupków, co udokumentowano w inklinometrze I-9 (ryc. 5; Wnuk i in., 2018).

Występowanie głębokich zlustrowań potwierdzono (Jurczak i in., 2019) w kolejnych 4 otworach o głębokości 31,5-40,0 m p.p.t. (ryc. 6). Rzędne stwierdzonych zlustrowań korelowały się z rzędnymi zlustrowań nawierconych we wcześniej wykonanych otworach (Wnuk i in., 2018), zwłaszcza z rzędnymi wychyleń kolumny inklinometrycznej w inklinometrach I-4 oraz I-9 (ryc. 3, 5). Zlustrowania występowały najgłębiej w otworze O-1 (27,5 m p.p.t.) i w otworze O-3 (26,1 m p.p.t.). Najniższe rzędne aktywnych stref poślizgu znajdowały się w otworach O-2 (24,5 m p.p.t.) oraz O-4 (22,4 m p.p.t.).

\section{WYNIKI BADAŃ}

W profilach otworów występuje zróżnicowanie utworów koluwialnych, których miąższość wynosi od 4 do $10 \mathrm{~m}$ (ryc. 6). Górna partia koluwiów składa się z gruntów średnio zwięzłych i bardzo spoistych, wykształconych jako gliny i iły z domieszką okruchów łupków i piaskowców. Poniżej gruntów spoistych w koluwiach tych występują mocno spękane łupki z przewarstwieniami mułowców

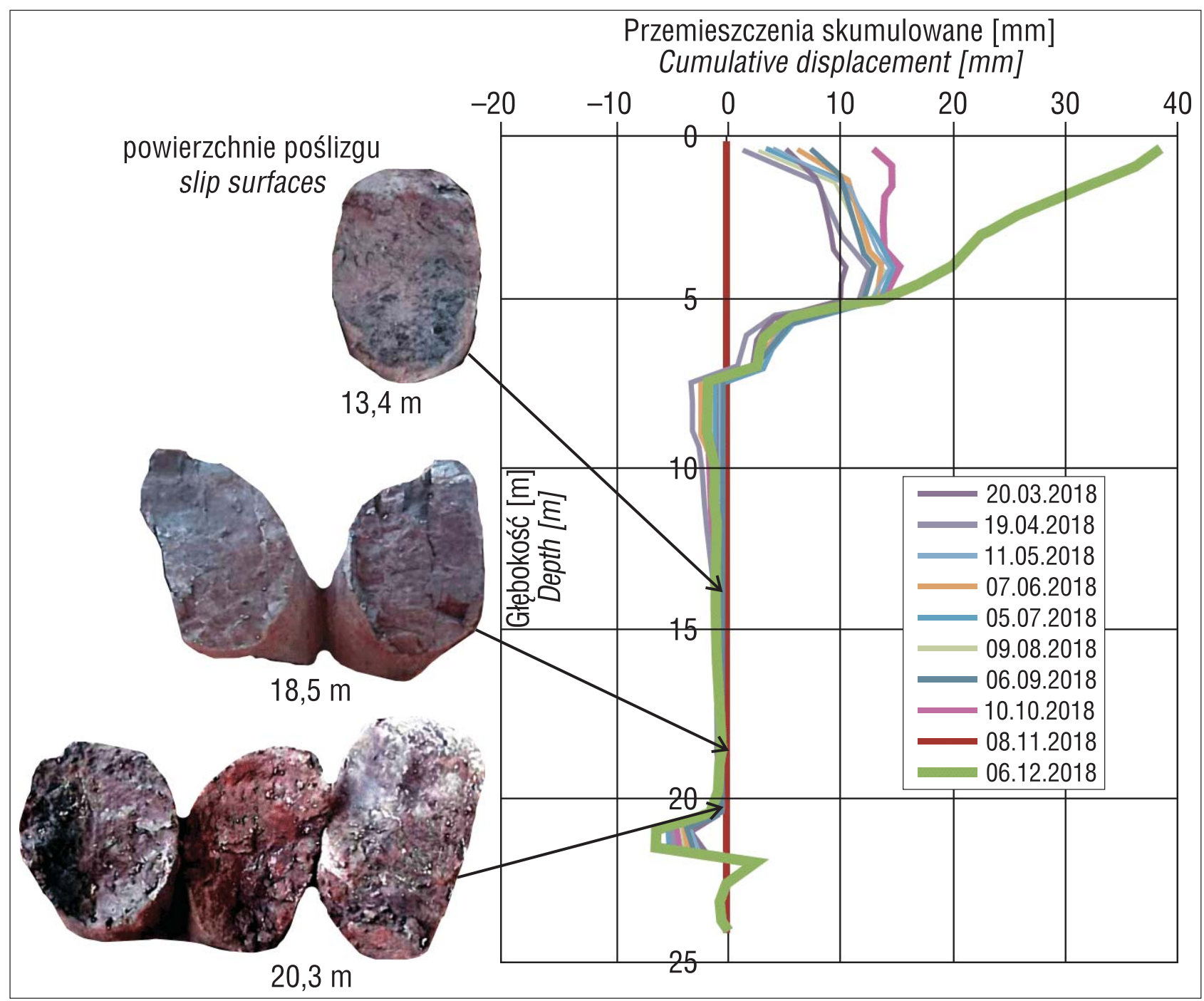

Ryc. 5. Krzywe kumulacyjne przemieszczeń w inklinometrze I-9 i fotografie powierzchni poślizgu

Fig. 5. Displacement curves in inclinometer I-9 and the photos of the slip surfaces 


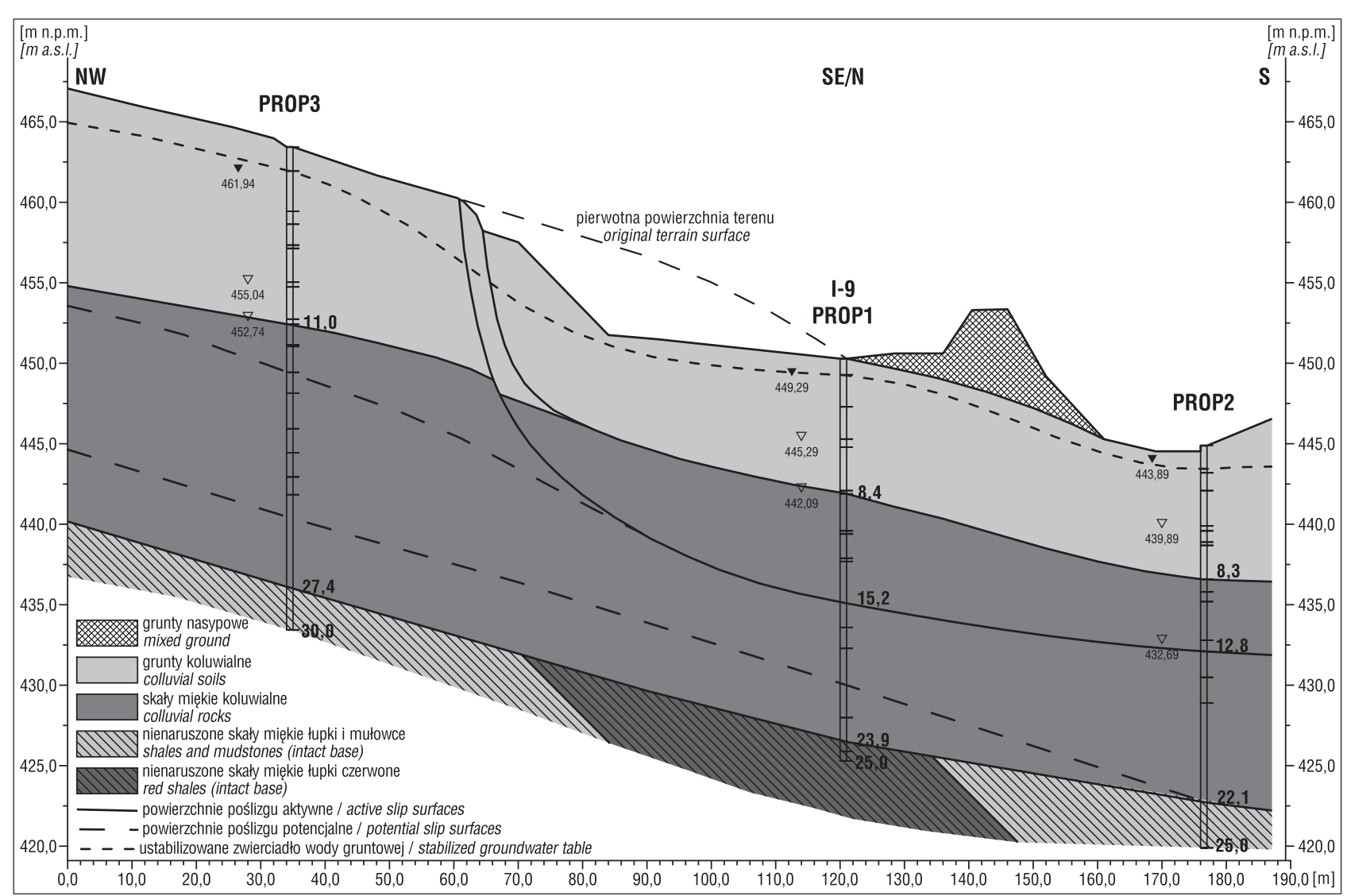

Ryc. 6. Przekrój geologiczno-inżynierski w rejonie drogi S-7 w Lubniu

Fig. 6. Geological-engineering cross-section through the region of the construction of the expressway S-7 in Lubien

i piaskowców o zmiennym upadzie oraz szczelinowatości (ryc. 6). Wyraźnie zaznaczają się w nich poziome i niskokątowe zlustrowania. W koluwiach osuwiskowych występują pakiety skalne, spękane i zrotowane względem siebie. Poniżej najniższej powierzchni poślizgu $(22,4 \mathrm{~m})$ materiał rdzeniowy jest niezaburzony, jego uławicenie jest regularne.

Uwzględniając różnice genetyczne i litologiczne gruntów oraz ich stan można było wyodrębnić 7 warstw geotechnicznych (łącznie z podgrupami). Z gruntów naturalnych, występujących w podłożu planowanej drogi, najmniej korzystne parametry ma warstwa gruntów spoistych w stanie plastycznym.

W otworach badawczych stwierdzono występowanie kilku aktywnych powierzchni poślizgu, na głębokości od 2,4 m (otwór O-2) do 10,4 m (otwór O-4). Ponadto, stwierdzono występowanie głębokich powierzchni poślizgu osuwiska strukturalnego - na głębokości od 15,1 m (otwór O-4) do 27,5 m (otwór O-1). Głębokość aktywnych powierzchni poślizgu została potwierdzona pomiarami w inklinometrach I-4 oraz I-9.

Zlustrowania mogą mieć dwojaką genezę. Mogą się wiązać z procesami osuwiskowymi lub tektonicznymi. Regułą jest, iż lustra spowodowane procesami tektonicznymi wykazują ślady mineralizacji, a kąty ich upadu są wysokie, także pionowe. Na obszarze badań dominuja lustra o małych kątach zapadania lub też są one prawie poziome i nie stwierdzono na nich śladów mineralizacji (ryc. 5, 6), co wskazuje na ich genezę osuwiskową. Ponadto w otworach badawczych do głębokości $10 \mathrm{~m}$ stwierdzono występowanie glin z rumoszami. Tak duża miąższość tego typu utworów wskazuje na występowanie koluwiów starego osuwiska lub ich genezę można wiązać z procesami soliflukcji w plejstocenie, co w tym przypadku wydaje się mało prawdopodobne.

W inklinometrze I-9 wykonano 10 pomiarów, z ich wyników jednoznacznie wynika, że przemieszczenia w otworze mają przebieg ciagły (ryc. 5), co wskazuje na istnienie głębokiego osuwiska strukturalnego. Przemieszczenia są bardzo wyraźne do głębokości $7 \mathrm{~m}$ p.p.t., gdzie dochodzą do $38 \mathrm{~mm}$, i są związane ze skarpą sztucznego wykopu. Mniejsze, ale wyraźne przemieszczenia zarejestrowano na głębokości ok. 21,0-22,5 m p.p.t. Występują one w skałach ilastych (łupki pstre), które ze względu na skład mineralny są podatne na osuwanie (Bober, 1983, 1984, 1994), zachodzące w tempie 0,5-1,5 mm na miesiąc.

Przemieszczenia w płytszych strefach gruntu, stwierdzone w inklinometrze I-9, świadczą o ich grawitacyjnej genezie, związanej z pracami ziemnymi wykonywanymi w tym rejonie. Problemem jest ocena genezy przemieszczeń występujących głębiej - poniżej koryta przepływającego w pobliżu cieku. Przemieszczenia te mogą być związane $\mathrm{z}$ ruchami osuwiskowymi lub utworzeniem się kawern $\mathrm{w}$ czasie wykonywania wiercenia albo $\mathrm{z}$ nieprawidłowym montażem kolumny inklinometrycznej oraz niedokładnym wypełnieniem przestrzeni między rurami inklinometrycznymi a gruntem. Obserwowane przemieszczenia osiagają wyższe wartości od błędów pomiarowych urządzenia. Obserwacje rdzeni przeprowadzone po wywierceniu otworów oraz inne dokumenty w postaci opisów i fotografii nie wskazują na błędy związane ze źle wykonanymi wierceniami i wykluczają występowanie kawern, a uzysk rdzenia był pełny.

Poniżej 23,9 m p.p.t. materiał skalny w rdzeniu nie był zaburzony, miał prawie pionowe uławicenie, nie wykazy- 
wał śladów przemieszczeń (ryc. 6). Powyżej, stwierdzono w nim wyraźne zaburzenia w ułożeniu warstw. Obserwowano fragmenty pokruszonej strzałki kalcytowej. Obserwacje te wskazują, że do głębokości $21,5 \mathrm{~m}$ p.p.t. występują grunty i skały, które ulegały przemieszczeniom (ryc. 5).

W profilu inklinometru I-9 istnieją dwie powierzchnie poślizgu: płytka i głęboka. Pierwsza, o zasięgu do $10 \mathrm{~m}$

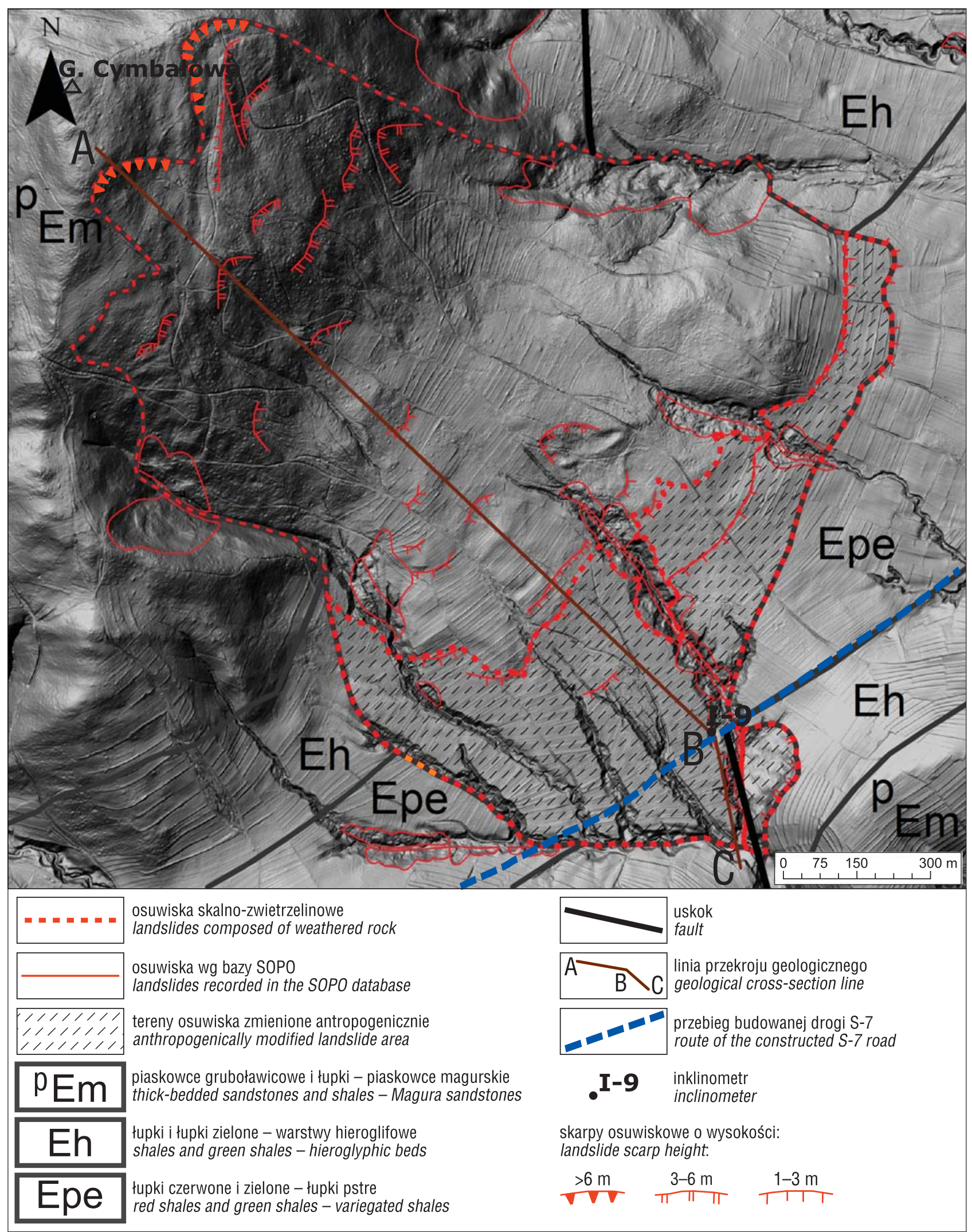

Ryc. 7. Rzeźba osuwiska na SE stokach Cymbałowej Góry na tle mapy geologicznej na modelu LiDAR (z danych CUGiK) Fig. 7. Relief of the landslide on the SE slopes of Mt. Cymbałowa and geological Map. In the digital terrain model from LiDAR data: Central Agency of Geodetic of Carthography Documentation (GODKGiK) Poland 


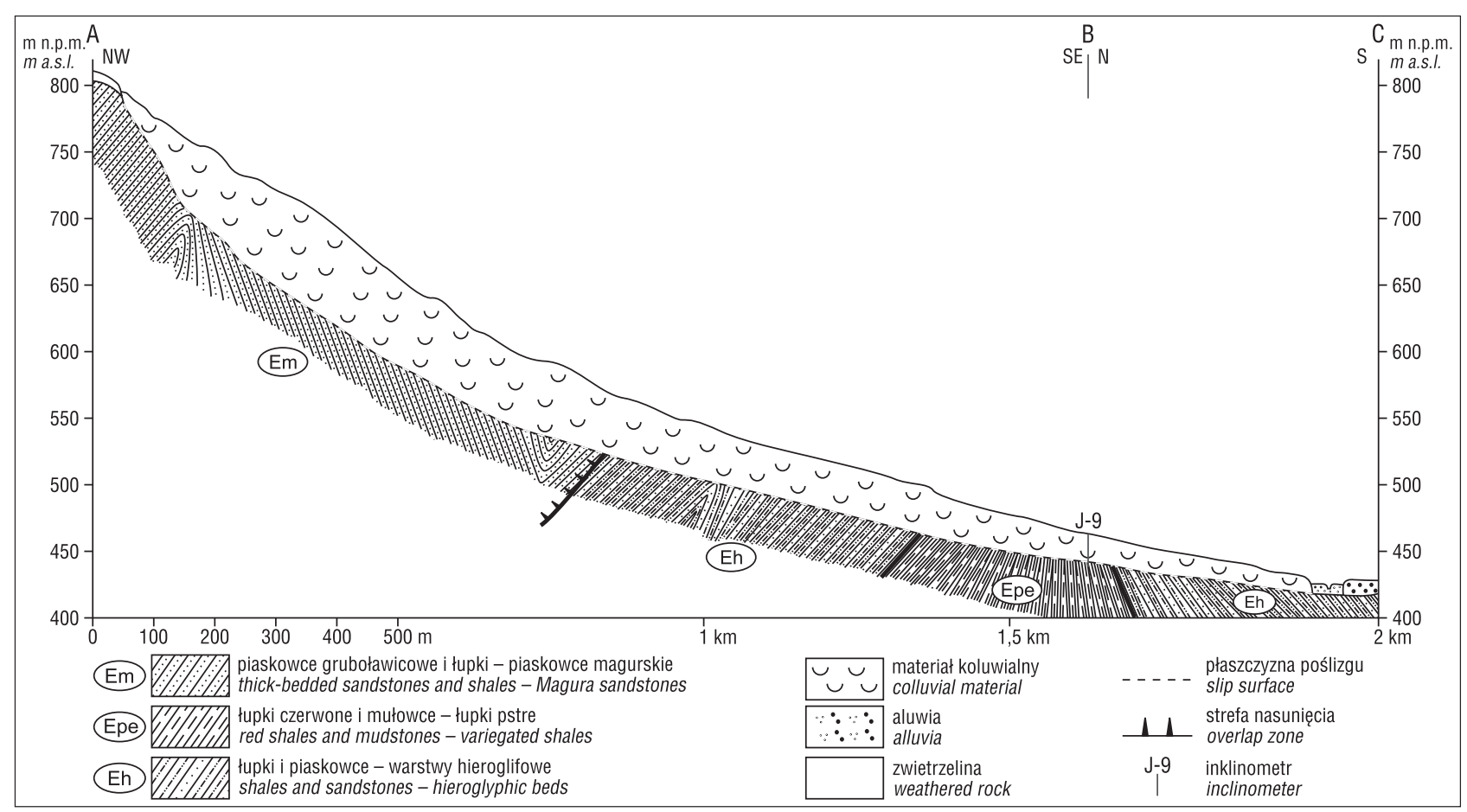

Ryc. 8. Schematyczny Przekrój geologiczny przez osuwisko na stokach Cymbałowej Góry

Fig. 8. Geological cross-section through the landslide on Mt. Cymbałowa slopes

głębokości, jest związana $\mathrm{z}$ istnieniem lokalnego rozcięcia oraz występowaniem głębokiego wkopu budowlanego. Powierzchnie głębokie wynikają z występowania słabych gruntów i skał, wykształconych w postaci łupków, a ślady zlustrowań świadczą o istnieniu powierzchni poślizgu na poziomie koryta potoku płynącego na południe od inklinometru I-9 (429 m n.p.m.).

Wyniki pomiarów inklinometrycznych jednoznacznie wskazują na istnienie przemieszczeń grawitacyjnych na głębokości poniżej $20 \mathrm{~m}$. Powstaje pytanie o ich genezę. Powyżej wysokości 490 m n.p.m. w terenie zaznaczają się nierówności oraz wyraźniejsze progi akumulacyjne, które są związane z procesami osuwiskowymi. Te wyraźne ślady kontynuują się aż do samego grzbietu Cymbałowej Góry (ryc. 7).

Obserwacje terenu poczynione powyżej inklinometru wskazują na możliwość występowania dużego, skalno-zwietrzelinowego osuwiska, rozpoczynającego się poniżej grzbietu Cymbałowej Góry, a kończącego się w potoku, znacznie poniżej inklinometru w kierunku południowym (ryc. 7, 8). Oględziny południowo-wschodnich stoków Góry Cymbałowej, przeprowadzone wiosną 2018 r., dowiodły istnienia dużego osuwiska skalno-zwietrzelinowego (ryc. 7). Rozpoczyna się ono poniżej grzbietu Góry Cymbałowej wyraźną skarpą osuwiskową, o wysokości sięgającej miejscami $15 \mathrm{~m}$ i o nachyleniu $30^{\circ}$. Tak znaczna wysokość skarpy głównej świadczy o dużej, prawdopodobnie, głębokości powierzchni poślizgu (ok. 40-45 m). Osuwisko ma formę złożoną - główna skarpa oraz górna partia tego osuwiska zostały założone na wychodniach piaskowców magurskich i w tej części osuwisko to ma kierunek obsekwentny (ryc. 8). Powierzchnia poślizgu w górnej partii przebiega $\mathrm{w}$ piaskowcach magurskich, a niżej w podścielających je warstwach hieroglifowych i pstrych łupkach (ryc. 8), które odsłaniają się w rejonie budowanej podpory P-2. Rzędna najniższej stwierdzonej powierzchni poślizgu w otworze I-9 (na głębokości 21,5 m) znajduje się na wysokości ok. 442,5 m n.p.m. i występuje na poziomie dna doliny potoku płynącego na południe od budowanej drogi.

Tak głęboka powierzchnia poślizgu mogła być uaktywniona w wyniku procesów grawitacyjnych zachodzących powyżej pasa drogowego, a uaktywnienie to mogło dodatkowo zostać spowodowane opadami atmosferycznymi (Pyrc, 2018). W przyszłości ruchy osuwiskowe mogą się nasilić w wyniku naprężeń dynamicznych lub w związku z wykonywanymi robotami ziemnymi bądź np. z palowaniem i związanymi z tym drganiami.

Z obserwacji wynika, że możliwe jest oddziaływanie osuwiska występującego na stokach Cymbałowej Góry na dolną części stoku, gdzie znajduje się inklinometr I-9 (ryc. 2, 5). Ponad inklinometrem I-9, w jego bezpośrednim sąsiedztwie, nie ma widocznych śladów przemieszczeń, a stok powyżej jest prosty, z licznymi tarasami rolniczymi. Prawdopodobnie został on w przeszłości sztucznie wyrównany przez intensywne użytkowanie rolnicze, czego pozostałością są tarasy śródpolne (ryc. 7). Na skutek występowania w podłożu serii skalnych, zawierających w przeważającej części łupki, ślady osuwiska w tej strefie mogły zostać całkowicie zatarte przez działalność rolniczą. $\mathrm{Z}$ tego względu nie wyklucza się, że przemieszczenia na głębokości poniżej $20 \mathrm{~m}$ są związane z oddziaływaniem dużego osuwiska, rozpoczynającego się w strefie podgrzbietowej Cymbałowej Góry (ryc, 7, 8).

\section{WNIOSKI}

Wyniki badań geologicznych wskazują, że ze względu na występowanie niekorzystnych procesów osuwiskowych teren, przez który przebiega nowy odcinek drogi ekspresowej S-7 w rejonie Lubnia, charakteryzuje się skomplikowanymi warunkami gruntowymi. 
Przemieszczenia obserwowane na głębokości 21-22 m $\mathrm{w}$ inklinometrze I-9 są związane $\mathrm{z}$ uruchomieniem głębokich powierzchni poślizgu starego, plejstoceńskiego osuwiska. Dotychczasowe obserwacje przemieszczeń wskazują, że mają one przebieg ciągły, a ich prędkość nie ulega zmniejszeniu.

Oddzielnym zagadnieniem jest stabilizacja osuwisk rozwiniętych na zboczach bocznej dolinki poniżej i powyżej podpory P-2, sposób ich zabezpieczenia i oddziaływanie na wykonywaną inwestycję. Zabezpieczenia powinny sięgnąc 3-5 m poniżej stref obserwowanych przemieszczeń i być wykonywane tak, aby zabezpieczyć podporę przed ich negatywnymi skutkami.

Uaktywnienie się głębokiego, strukturalnego osuwiska w rejonie drogi zostało spowodowane nałożeniem się kilku czynników. Jednym z nich były wysokie opady deszczu w 2017 r. (Pyrc, 2018). Kolejnym było wykonywanie wysokich i stromych skarp wykopów pod planowane fundamenty podpór drogi. Łącznym efektem tych czynników było uruchomienie stosunkowo płytkich osuwisk, o głębokości $8-11,0 \mathrm{~m}$. Odsłonięcie na znacznym obszarze gruntów ułatwiło infiltrację wód opadowych i gruntowych w głębsze strefy starego koluwium, co spowodowało ruchy osuwiskowe wzdłuż starych powierzchni poślizgu.

Rozpoznanie osuwisk, zwłaszcza w terenach zmienionych antropogenicznie, jest złożonym problemem. W obszarach, gdzie istnieją wątpliwości w kwestii występowania osuwisk, należy wykonywać dodatkowe, szczegółowe rozpoznanie geologiczne oraz instalować inklinometry, mogące rejestrować ruchy masowe i umożliwiające ostrzeganie przed ich ewentualnymi skutkami.

Właściwa analiza procesów osuwiskowych wymaga przede wszystkim dużego doświadczenia $\mathrm{w}$ dziedzinie badań geologicznych. Potwierdzeniem poprawności wnioskowania mogą być między innymi wyniki pomiarów przemieszczeń, wykonywane w otworach badawczych metoda inklinometryczną (Zabuski, 2013).

Autorzy składają podziękowania dr. hab. inż. Lesławowi Zabuskiemu - prof PAN, anomnimowemu Recenzentowi oraz Redakcji za cenne uwagi i komentarze.

\section{LITERATURA}

BOBER L. 1983 - Osuwiska dorzecza Raby. Kwart. Geol. 27 (2): 429-431.

BOBER L. 1984 - Rejony osuwiskowe w polskich Karpatach fliszowych i ich związek z budową geologiczną regionu. Biul. Inst. Geol., 340: $115-162$.

BOBER L. 1994 - Mapa dolin polskich Karpat fliszowych objętych degradacją wskutek ruchów masowych i eksploatacji kruszywa 1:200 000 . Państw. Inst. Geol. Warszawa: 30.

BORYSŁAWSKI A. 1985 - Budowa geologiczna płaszczowiny magurskiej między Tokarnią a Lubniem. Rozpr. doktorska. Centr. Arch. Geol. Państw. Inst. Geol.-PIB, Oddz. Karpacki, Kraków.

BURTAN J., SZYMAKOWSKA F. 1966 - Szczegółowa mapa geologiczna Polski 1:50 000 bez utworów czwartorzedowych, arkusz Osielec. Region Karpat i przedgórza. Wyd. tymczasowe. Inst. Geol., Warszawa. GRABOWSKI D., MARCINIEC P., MROZEK T., NESCIERUK P., RĄCZKOWSKI W., WÓJCIK A., ZIMNAL Z. 2008 - Instrukcja opracowania Mapy osuwisk i terenów zagrożonych ruchami masowymi w skali 1: 10000 . Państw. Inst. Geol.
GRZYWACZ W., KICIŃSKA K. 2000 - Dokumentacja geologiczno-inżynierska dla potrzeb koncepcji przebudowy drogi krajowej nr 7 Gdańsk-Warszawa-Chyżne na odcinku Lubień-Zabornia na drogę ekspresową II klasy technicznej S-7 w km 681+000 do 701+154 woj. małopolskie. Przedsiębiorstwo Usług Geologiczno-Laboratoryjnych Spółka z o.o. Chemkop-Laborgeo. Arch. Generalnej Dyrekcji Dróg Publicznych, Kraków.

JAKUBOWSKI K., OSTAFICZUK S. 1962 - Osuwisko w Pcimiu. Prz. Geol., 10 (11): 604-608.

JURCZAK S., RUSSOCKI M. 2017 - Dokumentacja badań podłoża gruntowego dla określenia możliwości zabezpieczenia podpór 1 i 2 obiektu $6+7+8$ przed skutkami ruchów masowych przy budowie drogi ekspresowej S-7 Kraków-Rabka Zdrój na odcinku Lubień-Naprawa w km 713+580 - 721+850. Przedsiębiorstwo Usług Geologiczno-Laboratoryjnych Spółka z o.o. Chemkop-Laborgeo, Kraków.

JURCZAK S., RUSSOCKI M., BANEK I., KULIG D. 2016 - Dokumentacja badań podłoża gruntowego dla kontrolnych prac geotechnicznych budowy drogi ekspresowej S-7 Kraków-Rabka Zdrój na odcinku Lubień-Naprawa w km 715+500 - 716+090. Obiekt 6+7+8. Przedsiebiorstwo Usług Geologiczno-Laboratoryjnych Spółka z o.o. Chemkop-Laborgeo, Kraków.

JURCZAK S., RUSSOCKI M., BANEK I. 2017 - Dokumentacja badań podłoża gruntowego dla określenia możliwości zabezpieczenia skarpy wkopu wykonanego w ramach budowy podpory II obiektu $6+7+8$ przy budowie drogi ekspresowej S-7 Kraków-Rabka Zdrój na odcinku Lubień -Naprawa w km 713+580 - 721+850. Przedsiębiorstwo Usług Geologiczno-Laboratoryjnych Spółka z o.o. Chemkop-Laborgeo, Kraków. JURCZAK S., WNUK M., JANIK K., KOZIK A., CYZ S., CHORABIK D., SUDER M. 2019 - Dokumentacja geologiczno-inżynierska dla zabezpieczenia osuwiska w miejscowości Lubień na działkach nr 10501 , 2925/58, 2930/89 - obręb ewidencyjny Lubień gmina: Lubień, pow. myślenicki, woj. małopolskie. AQUA-SOIL Mariusz Wnuk, Dąbrowa Górnicza.

KACZMARCZYK R., OLCHOWY P., OLSZAK J. 2010 - Mapa osuwisk i terenów zagrożonych ruchami masowymi w skala 1:10,000, gmina Lubień, Państw. Inst. Geol.-PIB.

KRÓLIKIEWICZ A. 1978 - Osuwiska na obejściu Mogilan. Osuwiska i sposoby zapobiegania im. Bibl. Drogownictwa. Wyd. Komunikacji i Łączności.

KSIAŻ̇KIEWICZ M., RACZKOWSKI W., WÓJCIK A. 2017 - Szczegółowa mapa geologiczna Polski w skali 1 : 50 : 000, ark Osielec. Państw. Inst. Geol.

MARGIELEWSKI W. 2006 - Records of the Late Glacial-Holocene paleoenvironmental changes in landslide forms and deposits of the Beskid Wyspowy Mts area (Polish Outer Carpathians). Fol. Quater., 76: 1-149.

MICHALIK A. 1970 - Mapa osuwisk w Karpatach 1:200 000. Centr. Arch. Geol. Państw. Inst. Geol., Oddz. Karpacki, Kraków.

NOWACKI J. (red.) 1999 - Instrukcja Obserwacji i Badań Osuwisk Drogowych. Generalna Dyrekcja Dróg Publicznych, Warszawa.

PIETRUSZA A., PLETNIA S. 2009 - Problemy utrzymaniowe związane z występowaniem osuwisk na odcinku drogi krajowej nr 7. [W:] Problemy osuwisk w budownictwie komunikacyjnym. Zesz. Nauk.-Tech. Stow. Inżynierów i Techników Komunikacji Rzeczpospolitej Polskiej, Oddz. w Krakowie, 88 (177): 251-286.

PIETRUSZKA B., MARSZAŁEK H., WAॄSIK M., HUDY K., HIPNER B. 2010 - Dokumentacja warunków geologiczno-inżynierskich sporządzona w związku z projektowaniem drogi ekspresowej S7 na odcinku Lubień-Rabka Zdrój oraz drogi nr 47 na odcinku Rabka Zdrój-Chabówka, część od początku odcinka do wlotu tunelu. Vepro Verkehrsbau Projekt GmbH-Berlin, Arch. Gen, Dyr. Dróg Publicznych, Kraków.

PYRC R. 2018 - Ekspertyza dotycząca warunków pluwialnych w miesiącu wrześniu na tle wielolecia 2011-2015 w Krzeczowie. Arch. IDS-BUD, Warszawa.

WNUK M., KOCHANOWSKA A., STEPCZYNSSKI A. CHORABIK D. 2018 - Sprawozdanie z badań - uzupełnienie DBPG dla określenia możliwości zabezpieczenia podpór 1 i 2 obiektu $6+7+8$ przed skutkami ruchów masowych przy budowie drogi ekspresowej S-7 Kraków-Rabka Zdrój na odcinku Lubień-Naprawa w km 713+580,22 - 721+197,24. AQUA-SOIL Mariusz Wnuk, Dąbrowa Górnicza.

WÓJCIK A., RĄCZKOWSKI W. 1994 - Objaśnienia do Szczegółowej mapy geologicznej Polski 1:50 000, arkusz Osielec (1015). Państw. Inst. Geol., Warszawa.

ZABUSKI L. 2013 - Ocena procesów osuwiskowych na podstawie pomiarów inklinometrycznych. Prz. Geol., 61 (4): 248-256. 